\title{
Evidence of Excess Returns on Firms That Issue or Repurchase Equity
}

\author{
William R. Nelson ${ }^{1}$ \\ Federal Reserve Board \\ November 1992 \\ Revised: January 1999
}

\begin{abstract}
Between 1927 and 1992, portfolios of the stock of the 5 percent of firms with the lowest annual growth in shares outstanding (generally a reduction in the change in shares) posted returns over the subsequent five years that averaged 12 percentage points more per year than the returns to portfolios of the 5 percent of firms with the highest highest annual growth in shares. The difference in returns is greater in more recent years and was positive for all of the final 33 years of the sample. The difference is apparent for portfolios of firms of all sizes and industries. The market beta of the returns to the portfolios of repurchasers exceeds only slightly that of the returns to the portfolios of issuers, insufficiently to account for more than a small part of the difference in average returns.
\end{abstract}

Keywords: Equity issuance, Equity repurchase, Excess returns

JEL Classification: G14, G35

1 Mail Stop 84, Federal Reserve Board, Washington D.C. 20551, Phone: (202) 452-3579, Fax: (202) 452-2301, Email: wnelson@frb.gov. The analysis and conclusions in this paper are those of the author and do not indicate concurrence by other members of the research staffs, by the Board of Governors, or by the Federal Reserve Banks. I gratefully acknowledge support for this research from the SSRC/NBER Subcommittee on Monetary Economics and the Anderson fellowship of the Cowles Foundation for Research on Economics. I would also like to thank William Brainard, Matthew Shapiro, Robert Shiller, William English, Spencer Krane, Athanasios Orphanides, and participants in the NBER Behavioral Finance Workshop for helpful advice and suggestions. All remaining errors are my own. 


\section{Evidence of Excess Returns on Firms That Issue or Repurchase Equity}

\section{Introduction}

There is fairly abundant evidence that stock returns contain a predictable component. At the aggregate level Fama and French (1988) and Poterba and Summers (1988) find that stock returns are serially correlated. Campbell and Shiller (1988) find that the dividend-price ratio forecasts future stock returns. Another branch documents differences in returns for firms of differing characteristics. Banz (1981) finds that average returns are negatively related to firm size and De Bondt and Thaler (1985) find that returns are negatively related to their past performance. Fama and French (1992) find that size and book-to-market value outperform a variety of other firm characteristics, including beta, in explaining the cross-section of variation of stock returns.

If the predictable component of returns owes to reasons other than variation in the amount and price of risk, owners of firms may correctly view their stock to be under or over valued. In this situation, they may be able to profit from their knowledge by repurchasing or issuing equity. This paper presents evidence that the stock of those firms that repurchase equity outperforms the stock of those firms that issue equity. Portfolios formed of firms that repurchase a significant amount of their own equity earn, on average, 12 percentage points more per year for the five years after the change in shares outstanding than portfolios of firms that issue a significant amount of equity.

It is possible that this difference in returns arises from differences in risk: firms that repurchase equity may be more highly leveraged than firms that issue equity. However, this 
does not appear to be the reason for the difference in returns since a conservative correction for market risk leaves large and significant excess returns. The excess returns are not limited to small firms, they are present for firms of all sizes. The abnormal performance has also become more pronounced in recent years. The portfolios of repurchasers of stock formed in 59 of the 67 years have outperformed the portfolios of issuers, including the portfolios formed in the final 33 years.

The strategy of this paper is to form portfolios of repurchasers and issuers of equity and measure their excess return. The year-end shares outstanding, corrected for stock splits and stock dividends, are used to calculate the change in shares outstanding for virtually all the firms traded on the NYSE between 1926 and 1992, after 1962, the AMEX, and after 1972, the Nasdaq. The change in shares is used to construct portfolios of buyers and sellers of equity in each year of the sample and the returns to the portfolios are calculated for the following five years. Since the change in shares is public information, the portfolio returns represent an implementable investment strategy. As is reported below, the portfolios of repurchasers earn a significantly positive excess return and the portfolios of sellers a significantly negative one. This result holds up for several rules for inclusion into the portfolios and within the three twenty-year subperiods.

The choice of the number of portfolios to consider was constrained by the behavior of the change in shares. In the first twenty years of the sample, firms rarely repurchased equity. Forming more than three portfolios (the firms that neither buy nor sell significant amounts of equity are also examined), would require discriminating among firms, all of whose shares outstanding were virtually unchanged. 
It seems plausible that the relationship between equity activity and future returns is the result of owners of firms reacting to perceived under or over valuation of their firms. In the absence of abundant arbitrage opportunities, under or over valuation must be highly serially correlated. The return horizon of five years is long enough to allow the valuation correction to influence the return, while not so long that the behavior of the returns is unrelated to the conditions giving rise to the equity transaction.

A great deal of research has been done on the reaction of stock prices to the announcement of stock offerings and tender offers. ${ }^{2}$ The general finding is that stocks rise when a repurchase is announced and drop when an issue is announced. The calculation of the returns reported in this paper begins in the year following an equity transaction, so the excess returns are in addition to the adjustment in price that occurs upon announcement. Other papers have documented long-horizon returns following the announcement of equity activity. Lakonishok and Vermaelen (1990) find abnormal returns for two years after repurchase tender offers but find the abnormal returns are limited to small firms. Ikenberry, Lakonishok and Vermaelen (1995) find a significant positive excess return for the four years after an announcement of a share repurchase. Loughran and Ritter (1995) find the stock of firms that engage in seasoned equity offerings tends to perform poorly over the following five years.

The research presented here differs from these studies in that it uses the change in shares outstanding as a measure of both issuance and repurchase. The change in shares

2 Dann (1981), Masulis (1980), Rosenfeld (1982), and Vermaelen (1981, 1984) examine abnormal returns around repurchase tender offers. Asquith and Mullins (1986), Masulis and Korwar (1986) and Mikkelson and Partch (1986) examine abnormal returns around the announcement of a new issue of common stock. 
allows for a longer sample and also measures whether firms actually, on net, issue or repurchase.

\section{Calculation of the portfolio returns}

The portfolio returns are calculated to replicate as closely as possible the return to investing in firms based on their issue or repurchases of shares. At the end of each year between 1926 and 1992, stocks are classified into one of three portfolios, a buy, sell, and hold portfolio: into the buy portfolio if their purchases of shares exceeds a threshold, into the sell portfolio if their sale of shares exceeds another threshold, and otherwise into the hold portfolio. Except where otherwise noted, the thresholds are adjusted each year so that 5 percent of stocks are classified into buy, 5 percent into sell, and 90 percent into hold. The return for each firm is calculated for the five years after inclusion in a portfolio with dividends reinvested. The residual funds (if any) from firms that do not last five years are reinvested equally among the remaining firms in the portfolio. Each firm remains in the portfolio it was assigned to for five years, regardless of its subsequent buy, hold, or sell status. Since the portfolios are formed annually and maintained for five years, in any given year there are five different vintages of portfolios under consideration, so the same firm may be simultaneously in a buy, hold, and sell portfolio from the different vintages.

\section{The data}

The data on stock returns and the change in shares are from the monthly Center for Research in Security Prices (CRSP) database. For inclusion in the sample, firms must have no missing values in capitalization (the total market value of equity) or shares outstanding, no 
consecutive missing values in returns, and must have at least two years of consecutive data -the minimum necessary to calculate the change in shares. Single missing values for returns are interpolated using the reported cumulative return from the last non-missing entry.

The change in shares is calculated using the calendar year-end value of shares outstanding corrected for stock splits and stock dividends. Shares outstanding change for reasons other than simple issues and repurchases of stock, for example, when warrants are exercised. It is desirable to have as broad a measure of financing on the equity margin as possible; to continue with the example of warrants, corporate insiders may exercise large blocks of warrants when they perceive their stock to be overvalued. Incorrect inclusion of firms into the portfolios of issuers and repurchasers at worst dilutes the resulting possible excess returns.

The returns are calculated by accumulating the monthly cum-dividend return for the five years following the calculation of the change in shares. The result is divided by five to give the annual return. ${ }^{3}$ The portfolios are created for each year from 1926 to 1992 . When results are reported by year they refer to the year in which the portfolio is formed. The portfolios begin equally weighted, except where noted.

When a firm is delisted, CRSP includes a final distribution if one can be found. If a final distribution is reported, it is used as the last return. If no final distribution is reported, the last reported return is used. Any residual funds from delisted firms are reinvested equally

3 This method of calculating the annual average return results in larger numbers than using logdifferences or taking the geometric mean. Log-differences are problematic because of bankruptcies, while geometric means complicate the calculation of market risk. Furthermore, the reader can simply multiply by five to recover the actual five-year return. 
among the remaining firms in the portfolio. The reasons for delisting by portfolio and over time are discussed below.

The end result is observations on more than 17 thousand firms with an average duration of about twelve years. The largest reason for exclusion is lack of observations for two or more years, followed by consecutive missing returns.

\section{Portfolio characteristics}

The behavior of share issuance and repurchase has changed over time. Table 1 contains information on equity transactions and on the portfolios. The fifth and ninety-fifth percentiles for the percent change in shares are presented in the first two columns of table 1. The average cutoff for the entire sample and for three subperiods are included at the bottom. These are the cutoffs used to form the portfolios, except where otherwise noted. During the first twenty years of the sample firms rarely repurchased shares -- the fifth percentile is consistently close to zero. Share issuance varies over the period, but on average is less than later in the sample. Except for a spike in 1946, share issuances and repurchases were much more common after the mid-1970s than in the earlier periods.

The third, fourth and fifth columns of table 1 contain the average percentage change in shares for the buy, hold, and sell portfolios defined using the fifth and ninety-fifth percentiles. Over the entire sample period the average change in shares of firms in the buy portfolio was negative 11 percent, shares of firms in the sell portfolio increased on average 100 percent, and in the hold portfolio the average change was 1.7 percent.

The firms in the buy and sell portfolios are, on average, slightly smaller than in the market as a whole. The final three columns of table 1 contain the percent of the total market 
value of the firms in the sample accounted for by the firms in the three portfolios. For the entire sample the buy portfolio contained 3.9 percent and the sell portfolio 2.9 percent of the total market value. Recall that both portfolios are chosen to contain 5 percent of the firms in the sample. ${ }^{4}$ As will be shown below, the smaller shares of market values in the two portfolios should not be interpreted as suggesting that the excess returns are limited to smaller firms.

The transitions between the portfolios, for firms that last more than one year, are shown in table 2. Regardless of what portfolio they were in, firms are most likely to end up in the hold portfolio in the next year. Firms that repurchased a significant amount of equity did so the next year 18.8 percent of the time, and issued a significant amount 4.6 percent of the time. Firms that issued a significant amount of equity continued to do so 13.9 percent of the time, and bought back a significant amount 4.5 percent of the time.

There is some difference across the portfolios as to the extent and reason for delisting. Table 3 presents the percent of firms delisted by year after the portfolio formation. For all the observations, 5.6 percent are gone by the second year. ${ }^{5}$ The portfolios are formed each year up to 1992, the final year that is followed by five years of returns. By the fifth year after an observation on the change in shares, 20.0 percent of the firms are gone.

4 In several of the initial years of the sample the portfolios of repurchasers or issuers contained less than 5 percent of the sample since less than 5 percent either decreased or increased their shares outstanding. On average, the buy portfolio contained 4.7 percent of the sample and the sell portfolio contained 4.9 percent.

5 It may seem plausible that some firms for which a change in shares is available are delisted before any return can be received, and thus are gone by the first year. To see why this can not happen recall how delistings are treated. If the firms are delisted during the year, any residual funds are invested in the market where they are held till the end of the year. If no return exists for January, then the final observation is for December. 
Both buyers and sellers are more likely to be delisted by the second year, buyers at 6.2 percent and sellers at 6.3 percent. By the end of five years 21.4 percent and 21.5 percent of the firms classified as buyers and sellers, respectively, are gone, slightly above the sample average.

Table 4 details the reasons for delisting. The percentages are of the firms delisted within the specified portfolios. Here, as elsewhere, the years refer to the year of the observation on the change in shares and thus the delisting occurred within the next five years. For the entire sample period sellers are less likely to be delisted due to a merger than are buyers or the remaining firms. Buyers are more likely to be delisted owing to an exchange of stock or to a liquidation. Sellers are more likely to be dropped by the stock exchange. ${ }^{6}$ The breakdown by sub-periods shows for all three portfolios an increase in the number of mergers and exchanges and a decrease in the number of liquidations and drops.

Table 5 presents the breakdown of observations in the three portfolios by one digit standard industrial classification code. The tendency to repurchase or issue equity does not appear to be related to industry type. The corporations in the portfolios of repurchasers and issuers of equity are distributed across industries in the same way as the sample as a whole.

\footnotetext{
${ }^{6}$ A firm can be dropped for a variety of reasons: they can be moved to another exchange, they can be dropped at the firm's request (for example, if the firm went private or bankrupt), or they can be dropped by the exchange for a failure to meet the requirements or follow the rules of the exchange.
} 


\section{Analysis of the portfolio returns}

The three portfolios exhibit markedly different returns in the five years after formation. These differences are robust to a conservative correction for market-risk. The excess returns appear for a variety of ways of defining portfolios. The difference tails off over the five years but exists and is generally significant throughout. The difference exists for firms of all sizes. The pattern across firms differing in the performance of their stock over the five years prior to the formation of the portfolio provides limited support of the view that the firms are issuing and repurchasing shares in anticipation of future excess returns.

\section{Comparison of the Raw Returns}

For the five years after inclusion in a portfolio the top five percent of repurchasers earn, on average, 12 percentage points more per year than the top five percent of issuers. Table 6 displays the portfolio returns per year, the average for the entire sample, and the average for the three subperiods. The annual returns to the portfolios of repurchasers and issuers is plotted in the top panel of Figure 1; the difference between the two is plotted in the bottom panel.

For the entire sample period, the portfolios of significant repurchasers of stock earned on average 27.8 percent, the portfolios formed of those that neither bought nor sold a significant amount earned 22.3 percent and the portfolios of those that issued a significant amount earned 15.6 percent. The difference between the buy and sell portfolios averaged 12.1 percentage points. Buy portfolios outperformed the sell portfolios in 59 of the 67 years.

Over the period 1926 - 1947 the buy portfolio and the hold portfolio both earned on average about 19 percent, above the sell portfolio which earned 15.1 percent. Recall that 
during this period there were very few instances of firms repurchasing their equity. For seventeen out of the twenty-two years the buy portfolio outperformed the sell portfolio. The average difference was 3.8 percentage points.

During the next period, 1948 - 1970, the return on the buy portfolio exceeded that on the hold portfolio 24.0 percent to 18.9 percent. The sell portfolio earned 15.0 percent resulting in an average margin between buy and sell of 9 percentage points. The buy portfolio exceeded the sell portfolio in twenty of the twenty-three years.

In the final period, 1971 - 1992, the buy portfolio earned 40.7 percent, the hold portfolio 29.1 percent and the sell portfolio 16.9 percent. Recall that the annual averages are calculated by simply dividing the five-year returns by five. The difference of 23.7 percentage points between buy and sell means that over the last twenty-two years an investor who had bought the buy portfolio would have ended with more than twice as much money after five years than one that made an equal investment in the sell portfolio. The investor would also have done better in buy than sell in each of the twenty-two years. Indeed, 1960 was the last year for which the portfolio of firms that sold stock performed better than the portfolio of firms that repurchased stock, resulting in thirty-three consecutive years in which repurchasers did better than issuers. ${ }^{7}$

The five years following 1974 appear to be an outlier. During those years the CRSP equally weighted index earned an annual return of 59.6 percent. The buy portfolio earned an annual return of 102.3 percent, the hold 77.6 percent and the sell 67.6 percent. Excluding the

7 When this paper was first written, in 1993, the final portfolio-formation year was 1985 . The 1998 revision allows for an out of sample evaluation of the investment strategy. The difference in five-year returns at an annual rate between the buy and sell portfolios formed in 1986 to 1992 averaged 18.8 percentage points. 
portfolios formed in 1974, the margin between buy and sell over the last twenty-two years narrows slightly to 23.2 percentage points.

\section{Correcting for Systematic Risk}

As mentioned in the introduction, there is reason to suspect firms that repurchase stock may be riskier than firms that issue stock. In the case where only the holding of debt is changed to compensate for the equity transaction, firms that repurchase stock would become more highly leveraged while those that issue stock would reduce their leverage. If the firms begin with similar leverage and risk, the stock of the firms that repurchased would become riskier than the stock of the firms that issued. On the other hand, some equity transactions may occur to normalize leverage. In this case, firms with low leverage would repurchase stock and those with high leverage would issue stock. If the adjustment is not complete, then the firms that issue would tend to be riskier than those that repurchase.

The procedure developed by Jensen (1969) allows for the calculation of abnormal returns after accounting for differences due to systematic risk. The procedure is based on the Sharpe-Lintner capital asset pricing model (henceforth CAPM).

Briefly, the CAPM states that the required return on any asset should equal the riskfree rate plus the asset's beta times a risk premium. The asset's beta is defined as the regression coefficient of the asset on the market as a whole. Defining $r_{i t}$ to be the return to asset $\mathrm{i}$ for time $\mathrm{t}, \mathrm{r}_{\mathrm{ft}}$ to be the risk-free rate in time $\mathrm{t}$, and $\mathrm{r}_{\mathrm{mt}}$ to be the market return at time $\mathrm{t}$, then the CAPM states that 


$$
\begin{aligned}
r_{i t} & =E_{t-1}\left\lfloor r_{i t}\right\rfloor+\beta_{i}\left(r_{m t}-E_{t-1}\left|r_{m t}\right|\right)+\boldsymbol{\varepsilon}_{i t}, \\
E_{t-1}\left[r_{i t}\right] & =r_{f t}+\beta_{i}\left(E_{t-1}\left[r_{m t}\right]-r_{f t}\right) .
\end{aligned}
$$

Moving the risk free rate over to the left-hand side and taking unconditional expectations yields Jensen's measure of abnormal returns --

$$
\left\lfloor r_{i t}-r_{f t}\right\rfloor=\alpha_{i}+\beta_{i}\left\lfloor r_{m t}-r_{f t}\right\rfloor+v_{i t} .
$$

The intercept is known as Jensen's alpha and is a measure of the excess return to a portfolio. If the CAPM is true then estimates of alpha should not be statistically different from zero. The period over which returns are calculated is not determined by the theory -- it should hold true at any interval, including the five-year interval used here.

Jensen's alpha is calculated for each portfolio using the five-year returns annualized by dividing by five. The returns are overlapping, consequently the error terms are probably serially correlated. While this will not bias the estimates of the coefficients, it will bias the standard errors. If the portfolios contained the same firms each year, the correct covariance matrix could be calculated directly. The four-year overlap would require covariances that decline linearly as the distance between observations grows from one to four years.

However, the firms are not in the same portfolio each year, so the extent of serial correlation is reduced. The standard errors are calculated using the Hansen (1982) - White 
(1980) procedure with the errors restricted to follow a fourth order moving average. ${ }^{8}$ The correction does not, in general, result in a large difference in the standard errors; this seems sensible since the idiosyncratic component of the returns to different firms in the same year should not be highly correlated.

Ex-post treasury bill returns taken from Ibbotson Associates (1997) are used to measure the risk-free rate. The market return is the return to all the firms in the sample. This market index is chosen for ease of exposition, since it eliminates the differences in return that arise through differences between how the portfolio is weighted and how the index is weighted. The portfolios are hybrids between equally weighted and market weighted. The portfolios begin equally weighted. In order to replicate the five-year holding return for each stock, after the first year the weights are the total gross return of the stock up to that year. The annual average of the five-year returns (at an annual rate) for all the observations in the sample is 22.2 percent, below the 23.8 percent for the CRSP equally-weighted return and above the 14.4 percent for the CRSP market-weighted return.

Jensen's alpha is a conservative test for abnormal returns. The difference between the annual average of the five-year return to treasury bills, 4.3 percent, and to the market (defined henceforth as the firms in the sample) is 17.9 percentage points, where, as throughout, all returns are at an annual rate. Empirical implementations of the CAPM invariably estimate a much smaller risk premium.

8 There is one exception to this procedure. In the estimates reported below on returns at each year after the formation of the portfolio (table 9) the Newey - West (1987) modification, with $\theta=1$, is used to force the covariance matrix to be positive definite. 


\section{Excess Returns for Various Definitions of the Portfolios}

Variation in systematic risk does not appear to explain the differences in average return across the portfolios. The top three lines of table 7 present the estimates of Jensen's alpha for the buy, hold and sell portfolios. The portfolios are constructed as described above -- each year the buy and sell portfolios contain the bottom and top five percent of firms by change in shares outstanding; the hold portfolio contains the remainder of firms. The returns are the five year holding returns for each portfolio at an annual rate. The alpha for the buy portfolio is 4.9 percent, for the sell portfolio it is negative 4.4 percent. Both estimates are highly significant. The estimates of the beta's are not in accord with the hypothesis that repurchasers of shares will be more risky than the market, although issuers of shares appear to be slightly less risky. The beta on the buy portfolio is 1.0 and on the sell portfolio it is 0.9. As can be seen by the standard deviations of the returns, the total risk to holding the buy portfolio is greater than the sell portfolio. A t-test strongly rejects the hypothesis that the means are the same $(t=3.3)$.

The rest of table 7 presents estimates of the average returns, alpha's, and beta's using alternative methods of constructing the portfolios. The bottom and top five percent of firms each year are good candidates for the portfolios when time variation in the mean level or dispersion of share repurchase or issuance does not anticipate or influence future excess returns. The second set of results is for portfolios formed using constant change-in-shares cutoffs to yield portfolios that contain five percent of firms overall, while varying in percent of firms each year. The results are quite similar to those for the time-varying cutoffs. The average return for the buy portfolio increases slightly but since the estimate of its beta is also 
increased, its alpha decreases slightly. The average return and estimated beta for the sell portfolio also increase slightly; on net its alpha is about unchanged. The rest of the results reported below use time-varying cutoffs.

The next set of estimates broadens the buy and sell portfolios to included the bottom and top ten percent of firms each year. The spread between the average returns of the buy and sell portfolios narrows slightly. The estimates of beta are little changed. Consequently, the alpha's decline to 3.6 percent and negative 3.4 percent respectively. Both alpha's remain highly significant.

The final set of estimates on table 7 begins to address the issue of firm size. The portfolios are formed with the five-percent cutoff, but the firms are assigned market weights. The estimates of average return both decline, but by about the same amount as the average return for the market as a whole. ${ }^{9}$ The estimated excess return of the buy portfolio, 6.2 percent, is higher than the estimate using equal weights. The excess return for the sell portfolio narrows slightly to negative 3.8 percent. Both estimates remain significant.

The pattern of average and excess returns is largely unchanged across definitions of the portfolios. Over the five years after an equity transaction, repurchasers of shares do better than the market and issuers of shares do worse. Correcting for systematic risk reduces the differences, but the remaining abnormal returns are statistically significant.

\footnotetext{
9 The market index for these estimates differs from the one used above. The index is the annual average of the five-year return to the firms in the sample, with the firms assigned market weights at the beginning of the five years.
} 


\section{Excess Returns in the Three Subperiods}

As noted above, there are differences in both the change in shares and the average returns to the portfolios across the three twenty-two-year subperiods. The amount of equity activity has gone up as has the spread between the portfolios. Table 8 presents the estimates of excess returns to the portfolios during the three subperiods. As there are only about twenty observations in each period, the estimates are imprecise.

From 1926 to 1947, repurchasers of stock did not do better than the market as a whole while issuers of stock did worse than the market and repurchasers. The beta's of both portfolios indicate they had less than normal systematic risk. While correcting for risk does bring the alpha for the buy portfolio into the positive range, it is not statistically significant. The alpha for the sell portfolio is negative 1.7 percent and it is highly significant.

In the middle years, 1948 - 1970, the buy portfolio earned a significantly positive excess return of 4.5 percent and the sell portfolio earned a significantly negative excess return of 3.6 percent. The estimates of beta are 1.0 for repurchasers and for issuers.

For the last twenty-two years, 1971 - 1992, the estimated excess returns widened further. The portfolio of equity repurchasers earned an excess return of 5.9 percent; the portfolio of issuers earned an excess return of negative 9.4 percent. Both estimates of excess returns are highly significant.

In summary, repurchasers of stock earn a statistically significant excess return in the last two subperiods, while issuers of stock earn a negative excess return which is highly significant in each subperiod. The estimates of beta rise from below one to well above one for repurchasers, and remain roughly equal to one for issuers. 


\section{Excess Returns at Each Year}

The average and excess returns for each of the five years after the equity transaction are reported in table 9. The returns on firms that repurchased equity exceeded those in the hold portfolio by $2.6,3.4,3.0,2.6$, and 3.2 percentage points for one to five years out. The spread of the buy portfolio over the hold portfolio remains surprisingly robust for over the

five years. For firms that issued equity the returns were below the hold portfolio by $5.5,4.8$, 2.6, 2.9, and 2.1 percentage points for the five years. The margins for the sell portfolio declines with the time since the stock issuance.

Alpha, the measure of excess return, for returns on both the buy and sell portfolios generally declines in magnitude as the years progress. The excess returns are significant for every year for both portfolios.

If the systematic risks of the two portfolios differ because of differences in leverage, then the beta of the buy portfolio should start below one, the beta of the sell should start above one and, as the other events return the firms to normal, both should converge to one as time progresses. The betas of both portfolios are essentially equal to one for all five years. Neither shows a pattern that suggests beta is capturing the effect of changes in leverage.

The estimates at the bottom of table 9 return to the annual average of the five-year returns, but use only the survivors -- those firms that did not disappear within five years after the formation of the portfolio. The results are very close to those using all the firms (reported at the top of table 7), even though this eliminates over 20 percent of the observations. 


\section{Controlling for Firm Size}

If the excess returns on firms that repurchase or issue stock were limited to small firms, the possible importance to the economy would be diminished. The estimates for the value-weighted portfolios presented above suggest the excess returns are not restricted to small firms. The results presented in table 10 confirm this finding. While the results are modestly more pronounced for small firms, they are present for all size categories of firms. For each year the firms are divided into size quintiles, referred to as very small, small, medium, large, and very large. Within the quintiles each year the bottom and top five percent of firms based on change in shares outstanding define the buy and sell portfolios.

The margin between the annual average return to the buy and sell portfolios is, in fact, greatest for medium-sized firms, 14.5 percentage points, followed by small and very small firms, tied at 9.2 percentage points, very large firms, 4.6 percentage points, and large firms, 4.6 percentage points.

After correcting for systematic risk, the portfolios of small firms have the largest and most significant excess returns, 4.8 percent for the buy portfolio and negative 8.9 percent for the sell portfolio. The excess returns for large firms are slightly smaller--4.3 percent for buy and negative 5.5 percent for sell--and are also significant. The excess returns on the buy portfolios made up of medium and very large firms are also significant.

The returns to the hold portfolios demonstrate the small firm effect. The annual average returns decline as firms' size grows, from 30.5 percent for very small firms to 15.3 percent for very large firms. However, the estimates of beta also decline with firm size. On net, none of the hold portfolios in the different size categories has significant excess returns. 


\section{Controlling for Past Performance}

Looking at firms whose stocks have experienced differing past performances may provide some information on the causal relationship between equity activity and excess returns. The subset of firms whose stock had done poorly may contain a larger fraction of undervalued firms. It is possible that a portfolio of those that did poorly and then repurchased their stock would include a larger fraction of firms that are issuing stock in anticipation of excess returns than in portfolios of repurchasers that did average or well. For issuers, the story is reversed. Firms whose stock had performed well may contain a greater fraction of overvalued firms.

Table 11 presents the results for the firms divided into quintiles based on the performance of their stock in the five years up to the formation of the portfolio. The subsets are referred to as very bad, bad, average, good, and very good. The sample of firms used differs slightly from elsewhere since a firm needs to have existed for five years to be classified.

Firms whose stock did very badly and then repurchased equity earned an annual average return of 37.6 percent over the next five years. If return reversal is a competing phenomenon, this number should be compared to the return to the sell portfolio of firms with similar past performance, 21.2 percent, yielding a margin of 18.4 percentage points. If return reversal is a complementary phenomenon, then the return should be compared either to firms that are most likely to be correctly valued or to those most likely to be undervalued. Firms whose stock had an average performance over the past five years and that neither issued nor repurchased equity in significant amounts earned 22.1 percent, a margin of 15.5 percentage 
points. Firms whose stock had a very good performance and then sold shares earned 15.3 percent, 22.3 percentage points below firms that did very badly and then repurchased stock. However, the portfolio of repurchasers with very bad past performance is extremely risky. The standard deviation of the return is more than twice as large as for the entire sample. Furthermore, the estimate of beta is sufficiently large, 1.9, to result in a negative, statistically insignificant excess return. The estimates of excess return are significant for the buy portfolios in the middle past performance quintiles--bad, average, and good; and for the sell portfolios in the extreme past performance quintiles--very bad, bad, and very good.

The returns to the hold portfolio across past performances demonstrate the tendency for stock returns to reverse themselves. Among the quintiles, the return falls monotonically as past performance is improved. In all cases, however, the difference in returns are accounted for by the differing beta's, which also fall with past performance, resulting in estimates of alpha that are not significantly different from zero except for significantly positive excess returns after average or good performance. 


\section{Comparison to Other Anomalies, Implications and Extensions}

The conclusion that firms experience significant excess returns after they buy or sell equity seems inescapable. The result is present for a variety of ways of classifying firms and for firms of all sizes. It has not gone away in recent years, but rather has become more pronounced. This section compares this result to other findings of anomalous behavior of stock returns and examines its implications for the economy as a whole.

\section{Comparison to Other Anomalies}

To ease comparison to two other anomalies, the same data and methodology are used to form portfolios based on firms' size and on their past performance. The buy and sell portfolios are formed each year using the bottom and top five percent of firms based on firm size and past performance. The results are reported in table 12, and should be compared to the results for the similar portfolios formed by change in shares reported at the top of table 7 .

Small firms outperform large firms by 21 percentage points. Losers outperform winners by 20.7 percentage points. Sorting by size or past performance results in nearly twice the margin between the two portfolios than the 12.1 percentage points difference between repurchasers and issuers of stock.

However, in both cases the difference in the beta's more than accounts for the margin in returns. The differences in systematic risk between portfolios based on size or past performance are much larger then when based on equity transactions.

These results probably reflect the fact that the excess returns following equity transactions are present for a broad class of firms, and thus are hard to explain by other firm characteristics. Some care should be taken when interpreting these results. They are 
presented only to help evaluate the magnitude and significance of the excess returns associated with equity transactions. They should not be taken to constitute evidence either for or against the two anomalies, which deserve more detailed attention. ${ }^{10}$

\section{Implications and Extensions}

The implications depend upon the causal relationship between equity transactions and excess return. If the equity transactions give rise to the excess returns, then the results presented here indicate the efficiency of the market is less than perfect, but not that the inefficiency is influencing the behavior of firms. If, on the other hand, the anticipation of the excess returns provokes the equity transactions, then deviations from fundamental value are influencing firm behavior.

The results do seem to indicate a degree of market inefficiency. The excess returns are statistically significant, implying the market is failing to react accurately to the public information contained in the repurchase or issuance of equity. Of course, it may be that the problem is with the correction for risk: If the appropriate correction were made there would not be any excess returns. It is never possible to reject a possibility. However, equity transactions suggested themselves as events that would precede excess returns if, in fact, the prices deviated from fundamental value; they did not present themselves because it had been observed that stocks did well after a repurchase and poorly after an issue. Thus, it would be an extraordinary coincidence if excess returns were found because of an incorrect correction for risk, precisely where other reasons suggested they might be found.

10 Chopra, Lakonishok, and Ritter (1992), for example, find economically significant return reversals when they use an empirically-determined price of market risk. 
The equity transaction may not have been made in pursuit of the excess returns. The sale of equity may reduce and the repurchase of equity may increase the value of the firm, albeit slowly. For example, perhaps mergers reduce the value of the acquiring firm and the predominance of stock issuance occurs to finance mergers. The reduction in value could come because firms generally pay too much, or because large, diversified firms are less efficient. Similarly, perhaps repurchases often come from firms which are streamlining or adopting the discipline of leverage. In both these cases, the inefficiency is in the speed at which the market corrects its assessment of the value of the firm. While this scenario is perhaps more likely than a miss-measurement of risk, the finding of excess returns nevertheless amounts to a coincidence.

Nevertheless, it seems likely that the excess returns reported here exist because some firms that perceive their stock to be overvalued issue and some that perceive their stock to be undervalued repurchase, and the reaction of the stock market to an issuance or repurchase is insufficient to remove the deviation of price from fundamental value. The portfolios of firms that issued equity contain a larger fraction of overvalued firms than the rest of the market. As stock prices that deviated from fundamental value return to normal, the firms experience negative excess returns. The portfolios of firms that repurchased equity contain a larger fraction of undervalued firms than the rest of the market.

A natural extension of this research is to examine the characteristics of the firms to see if there is any tendency for firms that appear undervalued to repurchase equity and for those that appear overvalued to issue equity. Furthermore, since firms repurchase and issue 
equity for a variety of reasons, it would be desirable to control for these reasons when forming the portfolios. ${ }^{11}$

If it can be established that firms are engaging in equity transactions in response to under or overvaluation, then a crucial question is the extent to which firms are changing their holdings of net financial versus their nonfinancial assets. Since firms cannot issue an infinite amount of equity or debt it is probable that overvaluation of their stock results in a lower cost of capital and undervaluation results in a higher cost of capital. Thus, it may be that the inefficiencies on the stock market impact the real economy.

Most capital investment is done by industrial firms, thus it is important to verify that the excess returns are being earned by this segment of the economy. Table 12 includes the results when the portfolios are constructed excluding firms in the service industry, those for which the first digit of their SIC is less than five. The results are, in fact, more pronounced than the results for the entire sample. Thus, establishing if the capital investment behavior of firms is influenced by under or over valuation seems an important extension of this research.

11 These extensions as well as many of those discussed below are examined in Nelson (1999). 
Table 1

Portfolio Characteristics

\begin{tabular}{|c|c|c|c|c|c|c|c|c|}
\hline \multirow{2}{*}{$\begin{array}{l} \\
\text { Year }\end{array}$} & \multicolumn{2}{|c|}{ Cutoff Percentiles } & \multicolumn{3}{|c|}{ Average Change in Shares } & \multicolumn{3}{|c|}{$\begin{array}{c}\text { Percent of Total } \\
\text { Market Value }\end{array}$} \\
\hline & P5 & P95 & Buy & Hold & Sell & Buy & Hold & Sell \\
\hline 26 & 0.0 & 16.7 & -5.5 & 0.4 & 78.0 & 4.0 & 88.2 & 7.8 \\
\hline 27 & 0.0 & 23.5 & -0.1 & 0.6 & 76.5 & 4.9 & 92.1 & 3.0 \\
\hline 28 & 0.0 & 49.2 & -4.5 & 2.0 & 90.3 & 2.8 & 91.4 & 5.8 \\
\hline 29 & 0.0 & 50.4 & -7.8 & 4.0 & 141.1 & 5.1 & 90.8 & 4.1 \\
\hline 30 & 0.0 & 20.0 & -5.8 & 0.6 & 72.6 & 5.0 & 77.7 & 17.3 \\
\hline 31 & 0.0 & 1.3 & -5.0 & 0.0 & 108.4 & 2.4 & 81.1 & 16.5 \\
\hline 32 & 0.0 & 0.0 & -9.9 & 0.0 & 101.5 & 2.0 & 93.5 & 4.4 \\
\hline 33 & 0.0 & 0.0 & -4.1 & 0.0 & 48.2 & 0.6 & 89.7 & 9.7 \\
\hline 34 & 0.0 & 0.0 & -0.8 & 0.0 & 29.4 & 0.5 & 91.3 & 8.1 \\
\hline 35 & 0.0 & 1.2 & -6.5 & 0.0 & 311.9 & 4.9 & 91.0 & 4.1 \\
\hline 36 & 0.0 & 15.2 & -3.6 & 0.4 & 169.7 & 1.5 & 96.3 & 2.1 \\
\hline 37 & 0.0 & 14.2 & -7.9 & 0.3 & 123.6 & 2.5 & 93.7 & 3.8 \\
\hline 38 & 0.0 & 0.0 & -6.4 & 0.0 & 44.7 & 4.3 & 88.5 & 7.2 \\
\hline 39 & 0.0 & 0.0 & -2.9 & 0.0 & 67.7 & 5.5 & 87.2 & 7.3 \\
\hline 40 & 0.0 & 0.0 & -9.4 & 0.0 & 51.8 & 4.6 & 87.3 & 8.1 \\
\hline 41 & 0.0 & 0.0 & -17.0 & 0.0 & 67.1 & 1.2 & 87.9 & 11.0 \\
\hline 42 & 0.0 & 0.0 & -2.9 & 0.0 & 32.2 & 2.6 & 94.6 & 2.8 \\
\hline 43 & 0.0 & 0.1 & -2.9 & 0.0 & 14.4 & 1.8 & 93.2 & 5.0 \\
\hline 44 & 0.0 & 0.0 & -10.1 & 0.0 & 22.1 & 2.1 & 84.8 & 13.2 \\
\hline 45 & 0.0 & 2.3 & -12.3 & 0.0 & 80.4 & 1.3 & 88.5 & 10.2 \\
\hline 46 & -10.6 & 66.2 & -27.1 & 6.1 & 249.2 & 1.6 & 94.6 & 3.8 \\
\hline 47 & -0.2 & 10.0 & -3.3 & 0.3 & 42.0 & 2.6 & 90.9 & 6.6 \\
\hline 48 & -0.3 & 8.6 & -4.3 & 0.2 & 23.9 & 10.2 & 84.7 & 5.1 \\
\hline 49 & -0.2 & 10.0 & -3.2 & 0.3 & 28.3 & 3.4 & 92.6 & 4.1 \\
\hline 50 & -0.5 & 14.3 & -6.3 & 0.6 & 44.1 & 3.7 & 92.0 & 4.3 \\
\hline 51 & -0.2 & 18.7 & -4.5 & 1.3 & 95.9 & 11.8 & 85.8 & 2.4 \\
\hline 52 & -0.2 & 18.1 & -2.9 & 1.2 & 362.0 & 7.4 & 89.2 & 3.4 \\
\hline 53 & -0.3 & 11.9 & -2.2 & 0.8 & 37.6 & 2.3 & 93.8 & 3.9 \\
\hline 54 & -0.3 & 13.3 & -3.9 & 1.0 & 42.1 & 1.4 & 89.0 & 9.6 \\
\hline 55 & -0.5 & 22.9 & -6.3 & 2.0 & 63.7 & 5.8 & 90.9 & 3.3 \\
\hline 56 & -1.0 & 17.8 & -4.1 & 1.8 & 72.8 & 0.8 & 97.8 & 1.4 \\
\hline 57 & -0.7 & 13.9 & -6.0 & 1.2 & 54.1 & 0.8 & 96.2 & 3.1 \\
\hline 58 & -1.3 & 13.8 & -5.5 & 0.9 & 41.4 & 0.9 & 96.3 & 2.8 \\
\hline
\end{tabular}


Table 1 (cont.)

Portfolio Characteristics

\begin{tabular}{|c|c|c|c|c|c|c|c|c|}
\hline & utoff & ntiles & Averag & thange & in Shares & & $\begin{array}{l}\text { net of } \\
\text { ket } V\end{array}$ & \\
\hline Year & P5 & P95 & Buy & Hold & Sell & Buy & Hold & Sell \\
\hline 59 & -0.4 & 14.1 & -6.5 & 1.4 & 40.2 & 2.2 & 95.0 & 2.8 \\
\hline 60 & -0.9 & 11.4 & -4.1 & 1.0 & 55.3 & 1.7 & 95.6 & 2.7 \\
\hline 61 & -0.9 & 13.2 & -6.1 & 1.1 & 54.3 & 1.7 & 96.8 & 1.5 \\
\hline 62 & -1.4 & 8.8 & -8.0 & 0.7 & 66.6 & 2.2 & 95.7 & 2.1 \\
\hline 63 & -0.8 & 6.7 & -4.1 & 0.3 & 38.6 & 2.8 & 92.7 & 4.5 \\
\hline 64 & -1.1 & 6.0 & -5.7 & 0.3 & 27.4 & 1.4 & 86.4 & 12.2 \\
\hline 65 & -0.8 & 8.2 & -4.8 & 0.5 & 29.4 & 4.0 & 91.5 & 4.5 \\
\hline 66 & -1.0 & 11.4 & -4.5 & 0.8 & 37.1 & 3.7 & 93.4 & 2.9 \\
\hline 67 & -0.2 & 17.4 & -3.4 & 1.2 & 44.4 & 4.5 & 91.3 & 4.3 \\
\hline 68 & -0.1 & 25.6 & -3.4 & 2.1 & 65.9 & 5.5 & 90.6 & 4.0 \\
\hline 69 & -0.2 & 19.7 & -1.8 & 1.5 & 46.6 & 5.8 & 91.6 & 2.5 \\
\hline 70 & -0.4 & 13.4 & -4.3 & 1.1 & 50.4 & 4.4 & 91.5 & 4.1 \\
\hline 71 & -0.2 & 14.5 & -2.5 & 1.1 & 41.0 & 2.5 & 94.3 & 3.2 \\
\hline 72 & -0.8 & 22.5 & -4.5 & 2.0 & 70.1 & 2.2 & 95.4 & 2.4 \\
\hline 73 & -0.0 & 0.6 & -3.5 & 0.0 & 477.3 & 7.0 & 86.2 & 6.7 \\
\hline 74 & -3.9 & 13.1 & -12.7 & 0.6 & 38.8 & 1.2 & 95.5 & 3.3 \\
\hline 75 & -4.2 & 13.0 & -13.3 & 0.6 & 33.2 & 1.3 & 93.6 & 5.2 \\
\hline 76 & -1.9 & 11.0 & -8.7 & 0.5 & 30.6 & 2.3 & 89.3 & 8.3 \\
\hline 77 & -5.5 & 15.7 & -16.0 & 1.1 & 35.2 & 1.0 & 94.0 & 4.9 \\
\hline 78 & -3.7 & 14.6 & -13.2 & 1.1 & 43.4 & 1.5 & 95.5 & 3.0 \\
\hline 79 & -3.6 & 16.1 & -11.7 & 1.2 & 43.7 & 2.1 & 93.9 & 4.1 \\
\hline 80 & -3.6 & 23.8 & -13.2 & 2.0 & 64.8 & 1.5 & 95.4 & 3.1 \\
\hline 81 & -4.1 & 28.3 & -12.9 & 2.6 & 78.5 & 2.9 & 94.1 & 3.1 \\
\hline 82 & -4.8 & 24.3 & -13.8 & 1.8 & 65.9 & 2.7 & 95.5 & 1.8 \\
\hline 83 & -3.3 & 39.1 & -13.0 & 4.6 & 96.7 & 2.6 & 95.2 & 2.2 \\
\hline 84 & -5.3 & 24.5 & -12.9 & 1.8 & 74.0 & 10.2 & 87.4 & 2.4 \\
\hline 85 & -4.2 & 32.9 & -14.6 & 2.9 & 86.1 & 6.9 & 91.2 & 1.9 \\
\hline 86 & -5.1 & 42.2 & -17.3 & 4.0 & 116.9 & 5.3 & 91.9 & 2.8 \\
\hline 87 & -6.2 & 40.8 & -17.1 & 3.2 & 123.2 & 3.7 & 94.4 & 1.9 \\
\hline 88 & -7.5 & 30.4 & -17.4 & 1.7 & 117.8 & 8.9 & 89.4 & 1.7 \\
\hline 89 & -6.0 & 29.6 & -16.4 & 2.1 & 139.0 & 4.0 & 92.8 & 3.2 \\
\hline 90 & -7.6 & 31.2 & -16.6 & 1.9 & 104.6 & 3.6 & 95.3 & 1.1 \\
\hline 91 & -4.4 & 38.5 & -14.2 & 3.2 & 133.7 & 2.5 & 96.1 & 1.4 \\
\hline 92 & -3.6 & 44.5 & -12.4 & 4.0 & 327.4 & 2.6 & 95.6 & 1.9 \\
\hline
\end{tabular}


Table 1 (cont.)

Portfolio Characteristics

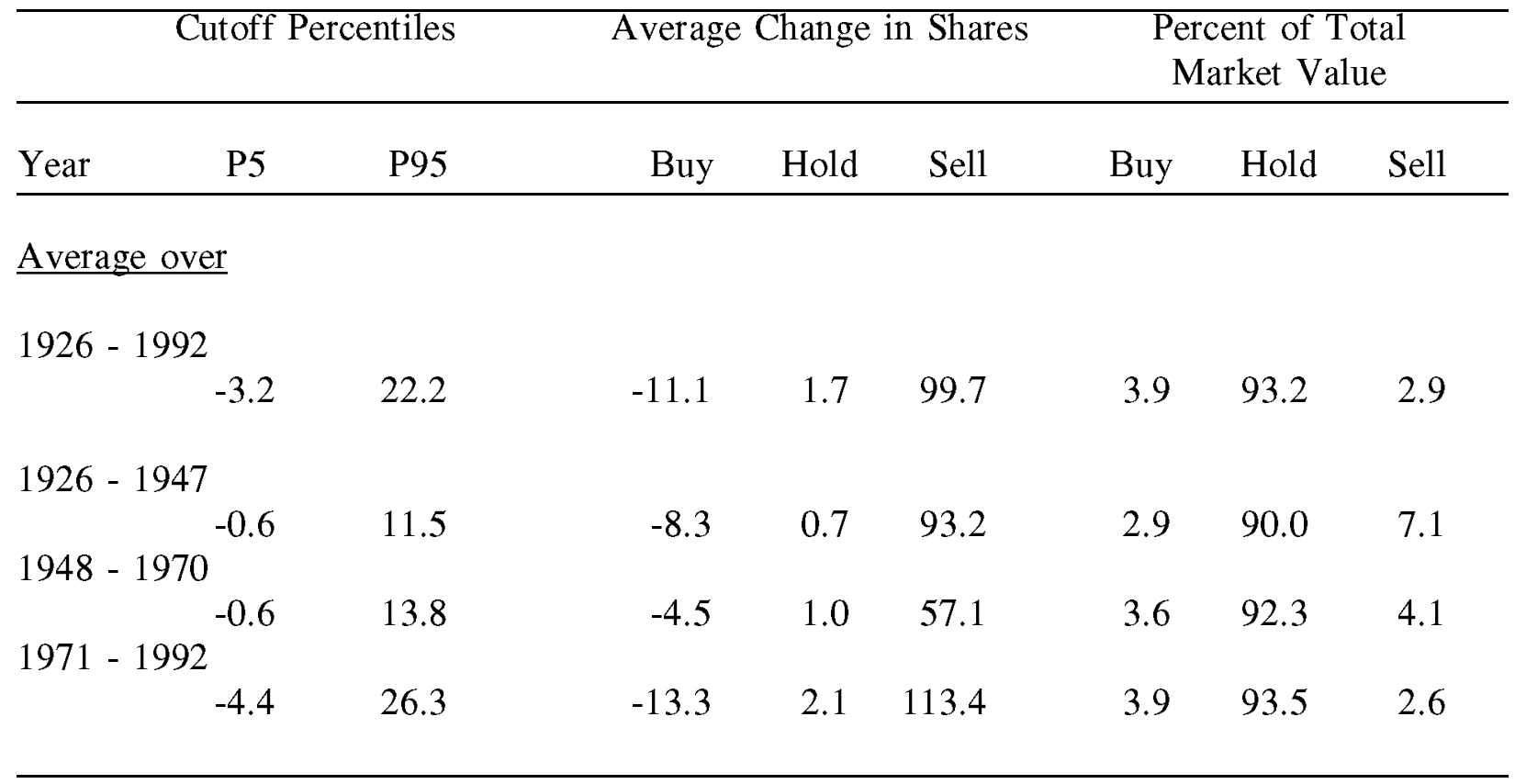

Note: The portfolios are formed each year based on the change in shares outstanding. The buy portfolio is the bottom five percent, the sell portfolio the top five percent and the hold portfolio the remainder. 
Table 2

Transitions Between Portfolios

\begin{tabular}{llccc}
\hline & & To & \\
\hline & & Buy & Hold & Sell \\
\hline \multirow{4}{*}{ From } & Buy & 18.8 & 76.6 & 4.6 \\
& Hold & 4.2 & 91.5 & 4.3 \\
& Sell & 4.5 & 81.6 & 13.9 \\
\hline
\end{tabular}

Note: For firms which lasted at least two years, this is the percent which ended up in the "to" portfolios which were in the "from" portfolios in the previous year. The buy portfolio consists of the bottom five percentiles based on the change in shares each year. The sell portfolio consists of the top five percent and the hold portfolio is the remainder. 
Table 3

Percent Delisted by Year After Formation of the Portfolio

\begin{tabular}{lcccc}
\hline Year & 2 & 3 & 4 & 5 \\
\hline Buy & 6.2 & 11.6 & 16.6 & 21.4 \\
Hold & 5.6 & 10.7 & 15.4 & 19.9 \\
Sell & 6.3 & 11.7 & 17.1 & 21.5 \\
A11 & 5.6 & 10.8 & 15.6 & 20.0 \\
\hline
\end{tabular}

Note: The buy portfolio is the bottom five percentiles based on the change in shares. The sell portfolio is the top five percentiles and the hold portfolio is the remainder. 


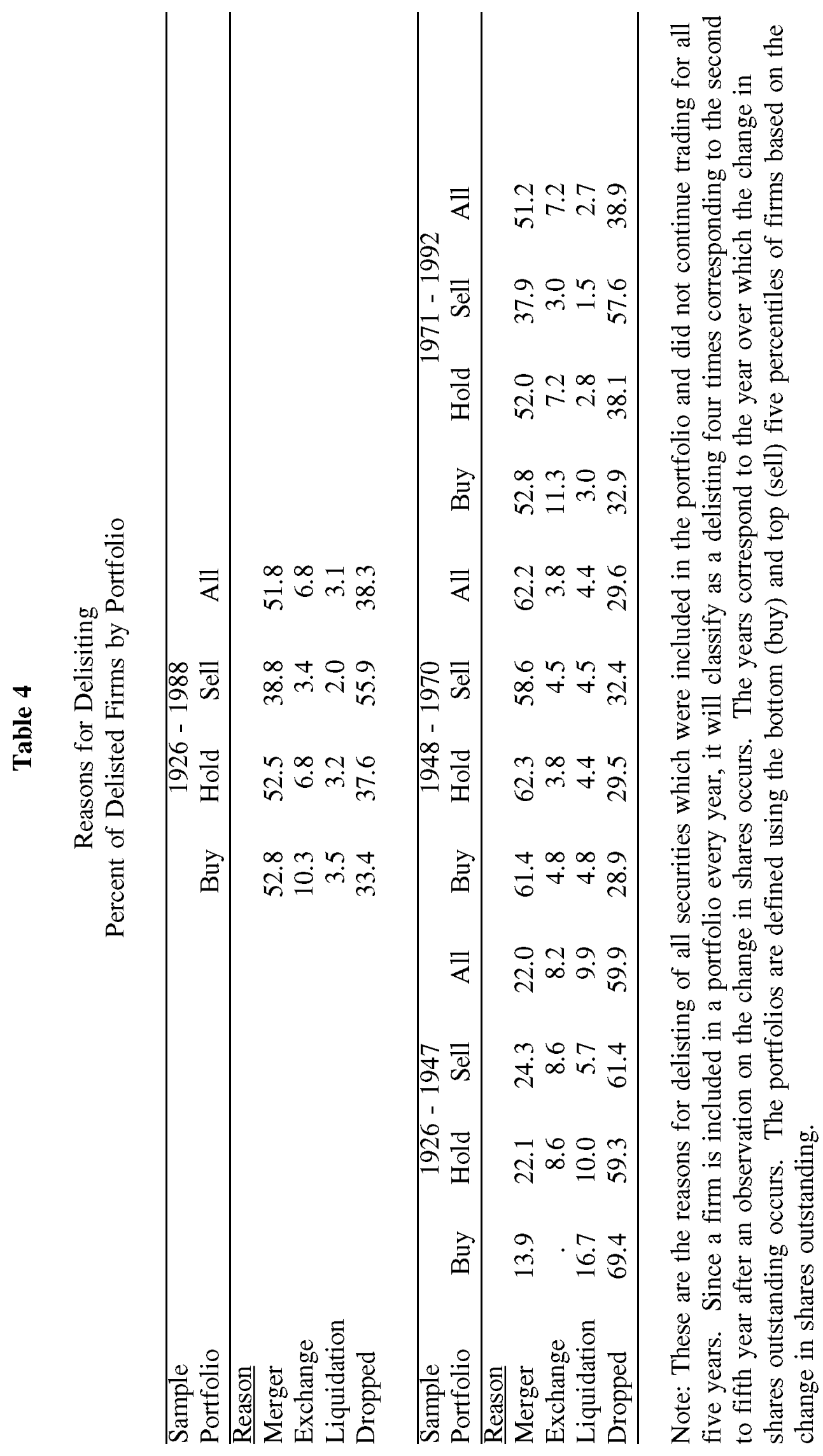




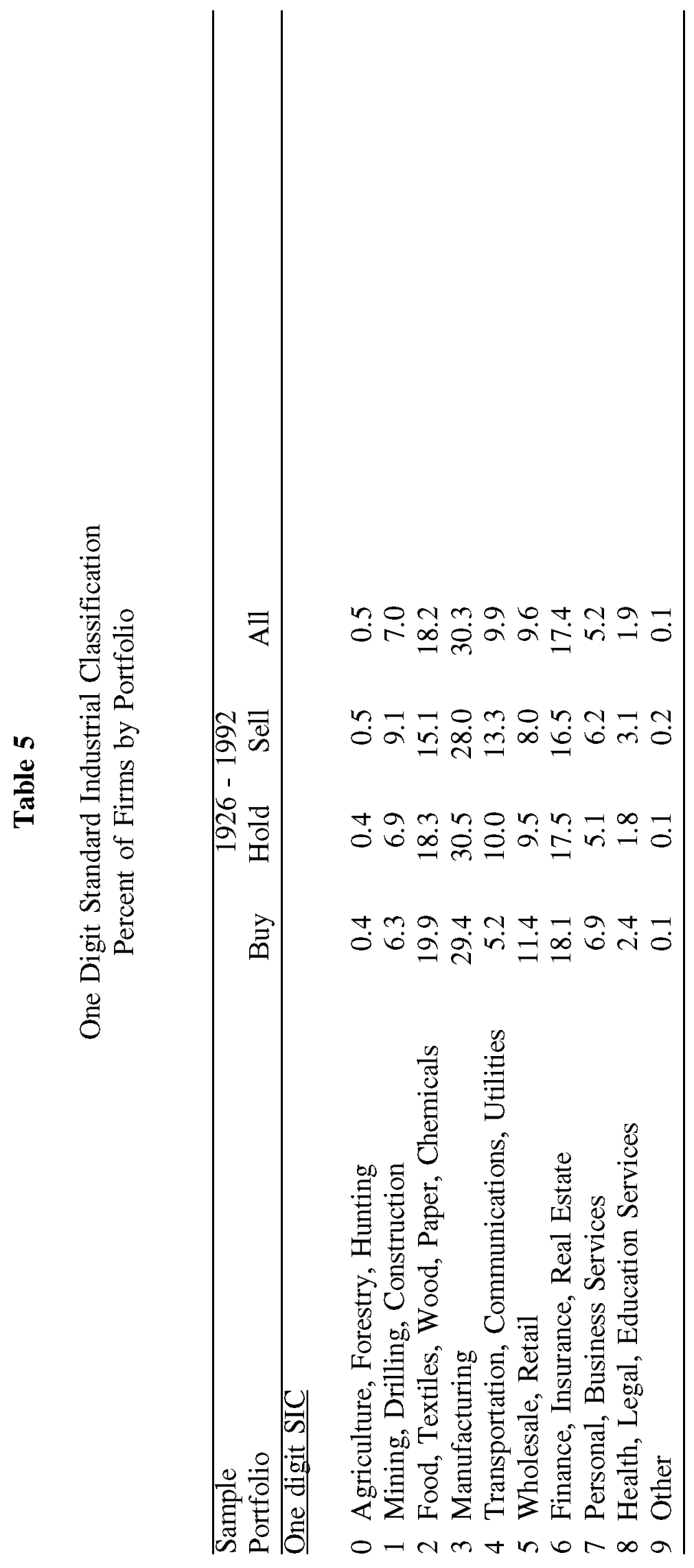




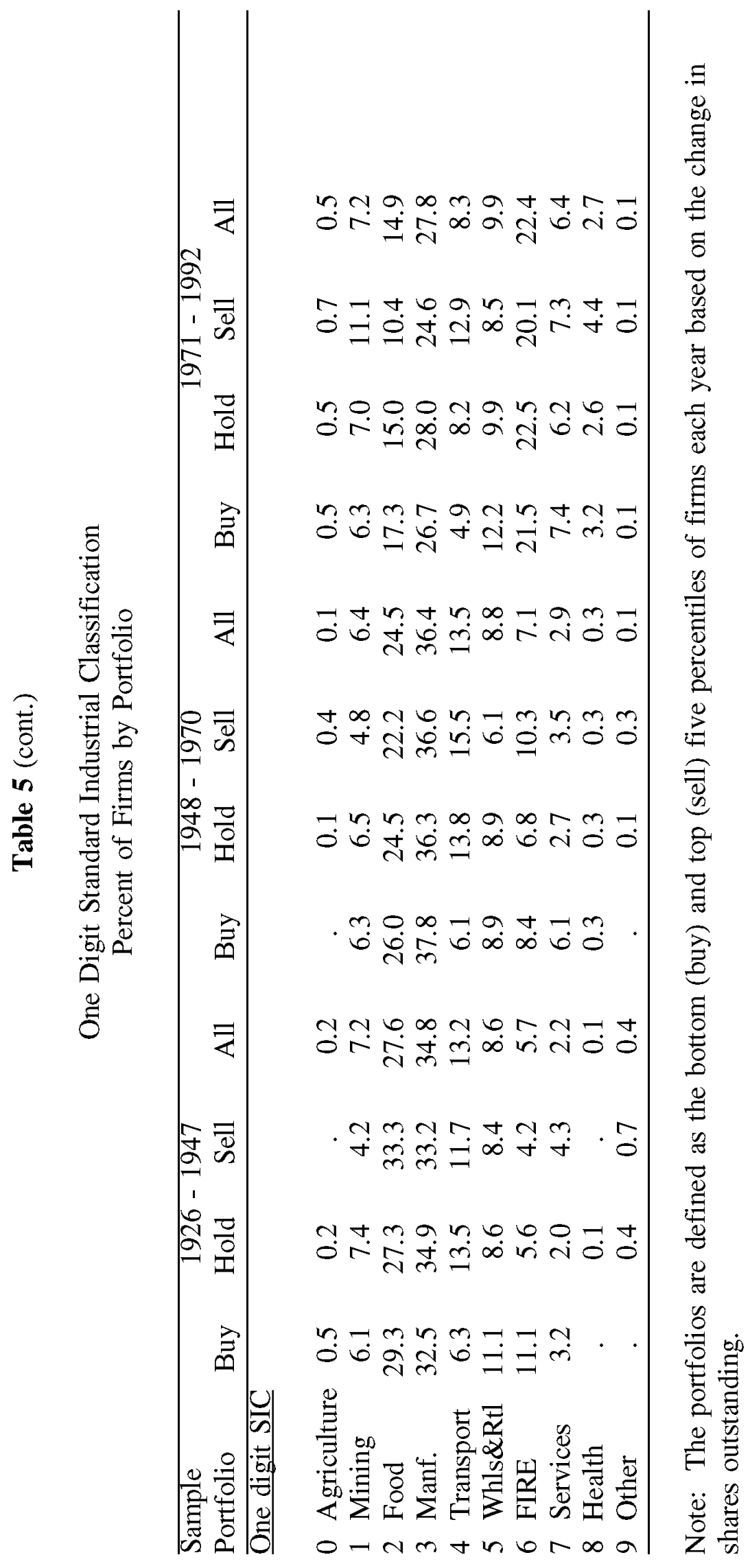




\section{Table 6}

Five-Year Returns on the Portfolios Formed by the Change in Shares by Year of Portfolio Formation, Percent, AR

\begin{tabular}{|c|c|c|c|c|}
\hline Portfolio & Buy & Hold & Sell & Buy-Sell \\
\hline \multicolumn{5}{|l|}{ Year } \\
\hline$\overline{1926}$ & -5.0 & -11.0 & -10.4 & 5.4 \\
\hline 1927 & -9.4 & -12.8 & -15.1 & 5.7 \\
\hline 1928 & -8.4 & -11.2 & -11.6 & 3.2 \\
\hline 1929 & -5.1 & -5.1 & -9.5 & 4.4 \\
\hline 1930 & 20.9 & 12.0 & 13.0 & 8.0 \\
\hline 1931 & 71.4 & 75.2 & 57.2 & 14.2 \\
\hline 1932 & 29.1 & 38.3 & 22.0 & 7.1 \\
\hline 1933 & 15.2 & 17.9 & 16.4 & -1.2 \\
\hline 1934 & 0.6 & 11.7 & 5.1 & -4.5 \\
\hline 1935 & 0.7 & -0.9 & -0.2 & 1.0 \\
\hline 1936 & -6.9 & -7.4 & -8.2 & 1.3 \\
\hline 1937 & 1.8 & 7.7 & 5.1 & -3.3 \\
\hline 1938 & 17.7 & 10.7 & 9.4 & 8.3 \\
\hline 1939 & 40.4 & 24.1 & 20.0 & 20.4 \\
\hline 1940 & 41.8 & 67.1 & 64.3 & -22.5 \\
\hline 1941 & 77.6 & 70.5 & 60.5 & 17.1 \\
\hline 1942 & 38.7 & 45.1 & 45.6 & -7.0 \\
\hline 1943 & 25.8 & 18.9 & 18.4 & 7.4 \\
\hline 1944 & 20.2 & 14.9 & 13.3 & 7.0 \\
\hline 1945 & 7.5 & 10.0 & 4.5 & 3.0 \\
\hline 1946 & 16.4 & 18.8 & 16.5 & -0.1 \\
\hline 1947 & 23.3 & 22.2 & 15.0 & 8.3 \\
\hline 1948 & 22.3 & 21.4 & 22.2 & 0.2 \\
\hline 1949 & 39.7 & 34.9 & 25.9 & 13.8 \\
\hline 1950 & 25.9 & 27.7 & 26.4 & -0.5 \\
\hline 1951 & 25.4 & 24.7 & 22.7 & 2.7 \\
\hline 1952 & 14.2 & 14.6 & 15.8 & -1.6 \\
\hline 1953 & 43.9 & 35.0 & 34.7 & 9.2 \\
\hline 1954 & 31.6 & 21.1 & 14.7 & 16.9 \\
\hline 1955 & 21.6 & 14.8 & 9.9 & 11.7 \\
\hline 1956 & 37.5 & 21.8 & 18.6 & 18.9 \\
\hline 1957 & 27.0 & 21.2 & 15.8 & 11.2 \\
\hline 1958 & 13.3 & 11.3 & 8.8 & 4.5 \\
\hline 1959 & 14.9 & 13.0 & 8.0 & 6.9 \\
\hline
\end{tabular}


Table 6 (cont.)

Five-Year Returns on the Portfolios Formed by the Change in Shares by Year of Portfolio Formation, Percent, AR

\begin{tabular}{lrrrr}
\hline Portfolio & Buy & Hold & Sell & Buy-Sell \\
\hline Year & & & & \\
1960 & & & & \\
1961 & 25.2 & 23.5 & 25.5 & -0.3 \\
1962 & 16.0 & 11.7 & 11.2 & 4.8 \\
1963 & 40.8 & 33.1 & 30.8 & 10.1 \\
1964 & 61.7 & 52.1 & 40.0 & 21.7 \\
1965 & 29.4 & 27.1 & 18.2 & 11.2 \\
1966 & 14.3 & 10.6 & 7.2 & 7.0 \\
1967 & 31.6 & 21.3 & 16.6 & 15.0 \\
1968 & 11.2 & 6.2 & -3.3 & 14.5 \\
1969 & -0.7 & -6.2 & -11.7 & 11.0 \\
1970 & -1.2 & -6.7 & -12.1 & 10.9 \\
1971 & 6.6 & 0.6 & -1.5 & 8.1 \\
1972 & 13.6 & 5.1 & 1.4 & 12.2 \\
1973 & 10.1 & 5.8 & 5.3 & 4.8 \\
1974 & 34.7 & 30.0 & 19.4 & 15.3 \\
1975 & 102.3 & 77.6 & 67.6 & 34.7 \\
1976 & 96.0 & 71.2 & 51.4 & 44.6 \\
1977 & 59.2 & 40.8 & 26.1 & 33.1 \\
1978 & 64.2 & 44.7 & 33.1 & 31.0 \\
1979 & 68.1 & 50.3 & 41.7 & 26.4 \\
1980 & 45.8 & 31.6 & 20.2 & 25.6 \\
1981 & 58.3 & 34.8 & 11.8 & 46.5 \\
1982 & 47.8 & 34.2 & 11.5 & 36.4 \\
1983 & 24.9 & 15.9 & 4.9 & 20.0 \\
1984 & 20.7 & 11.9 & -0.5 & 21.3 \\
1985 & 32.2 & 17.8 & 8.4 & 23.7 \\
1986 & 9.0 & 5.0 & -5.9 & 14.9 \\
1987 & 18.2 & 12.0 & 2.5 & 15.8 \\
1988 & 26.6 & 19.6 & 11.1 & 15.5 \\
1989 & 21.9 & 19.3 & 14.6 & 13.9 \\
1990 & 16.2 & 13.1 & 2.2 & 27.8 \\
1991 & 50.2 & 38.3 & 7.8 & 26.6 \\
1992 & 35.5 & 32.2 & 12.6 &
\end{tabular}


Table 6 (cont.)

Five-Year Returns on the Portfolios Formed by the Change in Shares by Year of Portfolio Formation, Percent, AR

\begin{tabular}{lcccc}
\hline Portfolio & Buy & Hold & Sell & Buy-Sell \\
\hline Average over & & & & \\
$1926-1992$ & 27.8 & 22.3 & 15.6 & 12.1 \\
$1926-1947$ & 18.8 & 18.9 & 15.1 & 3.8 \\
$1948-1970$ & 24.0 & 18.9 & 15.0 & 9.0 \\
$1971-1992$ & 40.7 & 29.1 & 16.9 & 23.7 \\
\hline
\end{tabular}

Note: The buy portfolio consists of the bottom five percent of firms each year based on the change in shares. The sell portfolio is the top five percent each year, and the hold portfolio is the remaining firms. The returns are over the following five years, and are annualized by dividing by five. The years are the date of portfolio creation so the return is for the subsequent five years. 
Table 7

Excess Returns for Various Definitions of the Portfolios

\begin{tabular}{llll}
\hline Portfolio & Return & Alpha & Beta \\
\hline
\end{tabular}

Bottom (buy) and top (sell) five percentiles of firms based on the change in shares each year

\begin{tabular}{lllllll}
\hline Buy & 27.8 & $(23.6)$ & 4.9 & $(1.3)$ & 1.0 & $(0.1)$ \\
Hold & 22.3 & $(20.5)$ & 0.0 & $(0.0)$ & 1.0 & $(0.0)$ \\
Sell & 15.6 & $(18.3)$ & -4.4 & $(1.4)$ & 0.9 & $(0.0)$
\end{tabular}

Constant cut-off to yield five percent of firms in each portfolio overall, but not each year

\begin{tabular}{lllllll}
\hline Buy & 28.4 & $(26.2)$ & 2.7 & $(1.5)$ & 1.2 & $(0.1)$ \\
Hold & 22.2 & $(20.3)$ & 0.2 & $(0.1)$ & 1.0 & $(0.0)$ \\
Sel1 & 17.5 & $(20.5)$ & -4.3 & $(1.4)$ & 1.0 & $(0.1)$
\end{tabular}

Top and bottom ten percent each year

$\begin{array}{lrrrrrr}\text { Buy } & 26.5 & (23.3) & 3.6 & (1.3) & 1.0 & (0.1) \\ \text { Hold } & 22.4 & (20.5) & 0.1 & (0.1) & 1.0 & (0.0) \\ \text { Sell } & 16.3 & (17.9) & -3.4 & (1.2) & 0.9 & (0.0)\end{array}$

Market weights (top and bottom five percent each year)

$\begin{array}{lrrrrrr}\text { Buy } & 21.7 & (16.8) & 6.2 & (2.2) & 1.1 & (0.1) \\ \text { Hold } & 15.0 & (11.1) & -0.0 & (0.0) & 1.0 & (0.0) \\ \text { Sell } & 11.5 & (12.2) & -3.8 & (1.0) & 1.0 & (0.1)\end{array}$

\begin{tabular}{lrr}
$\frac{\text { Aggregates }}{\text { Average of }}$ & & \\
sample & & \\
$\begin{array}{l}\text { T-Bills } \\
\begin{array}{l}\text { CRSP equally } \\
\text { weighted }\end{array}\end{array}$ & 22.2 & $(20.5)$ \\
$\begin{array}{l}\text { CRSP market } \\
\text { weighted }\end{array}$ & 23.8 & $(25.2)$ \\
\hline
\end{tabular}

Note: The portfolios are formed each year based on the change in shares outstanding. Except were noted, the buy portfolio is the bottom five percentiles, the sell portfolio is the top five percentiles and the hold portfolio is the remainder. The returns are for the five years following the creation of the portfolio and are annualized by dividing by five. Standard deviations of the returns and standard errors of the coefficients are in parentheses. The standard errors are corrected for possible serial correlation. 


\section{Table 8}

Excess Returns, Top and Bottom Five Percent

By Subperiods

\begin{tabular}{lccrrrr}
\hline Portfolio & \multicolumn{2}{c}{ Return } & \multicolumn{2}{c}{ Alpha } & \multicolumn{2}{c}{ Beta } \\
\hline 1926-1947 & & & & & & \\
Buy & 18.8 & $(24.1)$ & 2.1 & $(1.3)$ & 0.9 & $(0.0)$ \\
Hold & 18.9 & $(25.9)$ & 0.0 & $(0.0)$ & 1.0 & $(0.0)$ \\
Sell & 15.1 & $(23.2)$ & -1.7 & $(0.3)$ & 0.9 & $(0.0)$ \\
& & & & & & \\
1948 - 1970 & 24.0 & $(14.9)$ & 4.5 & $(1.0)$ & 1.0 & $(0.0)$ \\
Buy & 18.9 & $(13.6)$ & -0.0 & $(0.0)$ & 1.0 & $(0.0)$ \\
Hold & 15.0 & $(13.5)$ & -3.6 & $(1.2)$ & 1.0 & $(0.1)$ \\
Sell & & & & & & \\
1971 - 1992 & 40.7 & $(25.9)$ & 5.9 & $(1.5)$ & 1.3 & $(0.0)$ \\
Buy & 29.1 & $(19.7)$ & 0.2 & $(0.1)$ & 1.0 & $(0.0)$ \\
Hold & 16.9 & $(18.0)$ & -9.4 & $(1.6)$ & 0.9 & $(0.0)$ \\
Sell & & & & & & \\
& & & & & & \\
\hline
\end{tabular}

Note: The dates refer to the year in which the portfolios are formed. The portfolios are based each year on the change in shares outstanding. The buy portfolio is the bottom five percentiles, the sell portfolio is the top five percentiles and the hold portfolio is the remainder. The returns are for the five years following the creation of the portfolio and are annualized by dividing by five. Standard deviations of the returns and standard errors of the coefficients are in parentheses. The standard errors are corrected for possible serial correlation. 


\section{Table 9}

Excess Returns, Top and Bottom Five Percent

at Each Year After Formation of the Portfolio

\begin{tabular}{|c|c|c|c|c|c|c|}
\hline$\overline{\text { Portfolio }}$ & \multicolumn{2}{|c|}{ Return } & \multicolumn{2}{|c|}{ Alpha } & \multicolumn{2}{|c|}{ Beta } \\
\hline $\begin{array}{l}\text { Buy } \\
\text { Hold } \\
\text { Sell }\end{array}$ & $\begin{array}{l}20.0 \\
17.4 \\
11.9\end{array}$ & $\begin{array}{l}(29.8) \\
(30.6) \\
(33.1)\end{array}$ & $\begin{array}{r}3.9 \\
0.1 \\
-5.5\end{array}$ & $\begin{array}{l}(1.1) \\
(0.1) \\
(1.0)\end{array}$ & $\begin{array}{l}0.9 \\
1.0 \\
1.0\end{array}$ & $\begin{array}{l}(0.1) \\
(0.0) \\
(0.1)\end{array}$ \\
\hline $\begin{array}{l}\text { Year } 2 \\
\text { Buy } \\
\text { Hold } \\
\text { Sell }\end{array}$ & $\begin{array}{l}20.8 \\
17.4 \\
12.6\end{array}$ & $\begin{array}{l}(30.0) \\
(30.3) \\
(30.1)\end{array}$ & $\begin{array}{r}4.4 \\
-0.0 \\
-4.0\end{array}$ & $\begin{array}{l}(1.1) \\
(0.1) \\
(1.3)\end{array}$ & $\begin{array}{l}0.9 \\
1.0 \\
0.9\end{array}$ & $\begin{array}{l}(0.0) \\
(0.0) \\
(0.1)\end{array}$ \\
\hline $\begin{array}{l}\frac{\text { Year } 3}{\text { Buy }} \\
\text { Hold } \\
\text { Sell }\end{array}$ & $\begin{array}{l}19.4 \\
16.4 \\
13.8\end{array}$ & $\begin{array}{l}(29.9) \\
(29.3) \\
(30.2)\end{array}$ & $\begin{array}{r}3.1 \\
-0.0 \\
-2.6\end{array}$ & $\begin{array}{l}(0.8) \\
(0.1) \\
(1.2)\end{array}$ & $\begin{array}{l}1.0 \\
1.0 \\
1.0\end{array}$ & $\begin{array}{l}(0.0) \\
(0.0) \\
(0.0)\end{array}$ \\
\hline $\begin{array}{l}\text { Year } 4 \\
\text { Buy } \\
\text { Hold } \\
\text { Sell }\end{array}$ & $\begin{array}{l}19.2 \\
16.6 \\
13.7\end{array}$ & $\begin{array}{l}(28.4) \\
(27.8) \\
(29.8)\end{array}$ & $\begin{array}{r}3.0 \\
0.0 \\
-3.5\end{array}$ & $\begin{array}{l}(0.9) \\
(0.1) \\
(1.1)\end{array}$ & $\begin{array}{l}1.0 \\
1.0 \\
1.0\end{array}$ & $\begin{array}{l}(0.0) \\
(0.0) \\
(0.0)\end{array}$ \\
\hline $\begin{array}{l}\text { Year } 5 \\
\text { Buy } \\
\text { Hold } \\
\text { Sell }\end{array}$ & $\begin{array}{l}19.6 \\
16.4 \\
14.3\end{array}$ & $\begin{array}{l}(29.8) \\
(25.7) \\
(30.2)\end{array}$ & $\begin{array}{r}2.2 \\
0.0 \\
-3.6\end{array}$ & $\begin{array}{l}(1.1) \\
(0.1) \\
(1.0)\end{array}$ & $\begin{array}{l}1.1 \\
1.0 \\
1.1\end{array}$ & $\begin{array}{l}(0.1) \\
(0.0) \\
(0.1)\end{array}$ \\
\hline $\begin{array}{l}\text { Results fo } \\
\text { Buy } \\
\text { Hold } \\
\text { Sell }\end{array}$ & $\begin{array}{l}\frac{\text { vivors }}{27.5} \\
22.1 \\
16.4\end{array}$ & $\begin{array}{l}(22.8) \\
(19.8) \\
(18.0)\end{array}$ & $\begin{array}{r}4.8 \\
-0.0 \\
-3.9\end{array}$ & $\begin{array}{l}(1.1) \\
(0.0) \\
(1.2)\end{array}$ & $\begin{array}{l}1.0 \\
1.0 \\
0.9\end{array}$ & $\begin{array}{l}(0.1) \\
(0.0) \\
(0.0)\end{array}$ \\
\hline
\end{tabular}

Note: Non positive-definite estimates of the covariance matrix required implementation of the Newey-West (1987) procedure for these estimates. The portfolios are based each year on the change in shares outstanding. The buy portfolio is the bottom five percentiles, the sell portfolio is the top five percentiles and the hold portfolio is the remainder. Standard deviations of the returns and standard errors of the coefficients are in parentheses. The results for the survivors are the results when only firms which last for the subsequent five years are included in the portfolios. 
Table 10

Excess Return, Top and Bottom Five Percent

For Each Size Quintile

\begin{tabular}{lcccccc}
\hline Portfolio & \multicolumn{2}{c}{ Return } & \multicolumn{2}{c}{ Alpha } & \multicolumn{2}{c}{ Beta } \\
\hline Very small & & & & & & \\
Buy & 32.4 & $(36.2)$ & 1.1 & $(3.1)$ & 1.5 & $(0.1)$ \\
Hold & 30.5 & $(36.3)$ & -4.5 & $(3.1)$ & 1.7 & $(0.1)$ \\
Sell & 23.2 & $(33.5)$ & -6.3 & $(4.2)$ & 1.4 & $(0.2)$ \\
Small & & & & & & \\
Buy & 29.2 & $(30.8)$ & 4.8 & $(2.3)$ & 1.1 & $(0.3)$ \\
Hold & 24.5 & $(24.0)$ & -0.5 & $(0.9)$ & 1.2 & $(0.1)$ \\
Sell & 20.0 & $(31.3)$ & -8.9 & $(2.8)$ & 1.4 & $(0.1)$ \\
& & & & & & \\
Medium & & & & & & $(0.1)$ \\
Buy & 31.3 & $(26.8)$ & 6.8 & $(1.9)$ & 1.1 & $(0.0)$ \\
Hold & 22.0 & $(19.8)$ & 0.7 & $(0.5)$ & 0.9 & $(0.1)$ \\
Sell & 16.8 & $(21.2)$ & -2.6 & $(2.6)$ & 0.9 & \\
& & & & & & \\
Large & & $(18.2)$ & 4.3 & $(1.8)$ & 0.7 & $(0.1)$ \\
Buy & 20.9 & $(16.1)$ & 1.7 & $(1.3)$ & 0.7 & $(0.1)$ \\
Hold & 19.3 & $(23.2)$ & -5.5 & $(2.0)$ & 1.0 & $(0.2)$ \\
Sell & 16.3 & & & & & \\
& & & & & & \\
Very Large & 20.9 & $(16.1)$ & 4.8 & $(2.0)$ & 0.7 & $(0.0)$ \\
Buy & 15.3 & $(11.5)$ & 2.8 & $(2.1)$ & 0.5 & $(0.1)$ \\
Hold & 13.1 & $(14.5)$ & -2.0 & $(2.0)$ & 0.6 & $(0.1)$ \\
Sell & & & & & & \\
& & & & & &
\end{tabular}

Note: Size is measured by market value of equity. Each year, within the size quintiles, the buy, hold, and sell portfolios are based on the change in shares outstanding. The buy portfolio is the bottom five percentiles, the sell portfolio is the top five percentiles and the hold portfolio is the remainder. The returns are for the five years following the creation of the portfolio and are annualized by dividing by five. Standard deviations of the returns and standard errors of the coefficients are in parentheses. The standard errors are corrected for possible serial correlation. 


\section{Table 11}

Excess Return, Top and Bottom Five Percent

For Each Past Performance Quintile

\begin{tabular}{lcccccc}
\hline Portfolio & \multicolumn{2}{c}{ Return } & \multicolumn{2}{c}{ Alpha } & & \\
\hline Very bad & & & & & & \\
Buy & 37.6 & $(39.6)$ & -1.3 & $(3.1)$ & 1.9 & $(0.2)$ \\
Hold & 30.2 & $(31.6)$ & -6.9 & $(4.6)$ & 1.8 & $(0.3)$ \\
Sell & 21.2 & $(30.4)$ & -11.5 & $(3.9)$ & 1.6 & $(0.2)$ \\
& & & & & & \\
Bad & & & & & & \\
Buy & 30.9 & $(24.3)$ & 5.0 & $(2.6)$ & 1.1 & $(0.2)$ \\
Hold & 25.1 & $(19.1)$ & 0.5 & $(0.6)$ & 1.1 & $(0.0)$ \\
Sell & 22.5 & $(22.2)$ & -2.8 & $(0.9)$ & 1.1 & $(0.1)$ \\
& & & & & & \\
Average & & & & & & \\
Buy & 29.6 & $(20.7)$ & 7.2 & $(1.7)$ & 0.9 & $(0.1)$ \\
Hold & 22.1 & $(15.2)$ & 1.8 & $(0.8)$ & 0.9 & $(0.1)$ \\
Sell & 16.3 & $(12.5)$ & 1.3 & $(2.4)$ & 0.6 & $(0.1)$ \\
& & & & & & \\
Good & & & & & & \\
Buy & 25.2 & $(21.3)$ & 9.6 & $(4.9)$ & 0.6 & $(0.3)$ \\
Hold & 19.6 & $(12.2)$ & 3.0 & $(1.8)$ & 0.7 & $(0.1)$ \\
Sell & 15.8 & $(14.0)$ & -0.0 & $(1.6)$ & 0.6 & $(0.1)$ \\
& & & & & & \\
Very good & & & & & & \\
Buy & 20.7 & $(18.6)$ & 1.2 & $(2.3)$ & 0.8 & $(0.1)$ \\
Hold & 17.3 & $(11.8)$ & 1.7 & $(2.1)$ & 0.6 & $(0.1)$ \\
Sell & 15.3 & $(18.4)$ & -5.2 & $(1.7)$ & 0.9 & $(0.1)$ \\
& & & & & & \\
\hline
\end{tabular}

Note: The quintiles are based on the stock return over the five years up to the formation of the portfolio. Each year, within the past performance quintiles, the buy, hold, and sell portfolios are based on the change in shares outstanding. The buy portfolio is the bottom five percentiles, the sell portfolio is the top five percentiles and the hold portfolio is the remainder. The returns are for the five years following the creation of the portfolio and are annualized by dividing by five. Standard deviations of the returns and standard errors of the coefficients are in parentheses. The standard errors are corrected for possible serial correlation. 
Table 12

Comparison to Other Anomalies and Restriction to Industrial Firms

\begin{tabular}{|c|c|c|c|c|c|c|}
\hline Portfolio & & & & & & \\
\hline Portfolios & $\mathrm{d}$ on $\mathrm{f}$ & size & & & & \\
\hline Small & 34.6 & $(49.6)$ & -8.3 & (6.7) & 2.2 & $(0.4)$ \\
\hline Medium & 22.0 & $(20.2)$ & 0.2 & $(0.3)$ & 1.0 & $(0.0)$ \\
\hline Big & 13.6 & $(10.5)$ & 3.9 & (2.6) & 0.3 & $(0.1)$ \\
\hline Portfolios & st perf & ince & & & & \\
\hline$\overline{\mathrm{Bad}}$ & 37.0 & $(58.1)$ & -21.1 & (11.2) & 2.8 & $(0.7)$ \\
\hline Fair & 23.5 & (16.9) & 1.2 & $(0.5)$ & 0.9 & $(0.0)$ \\
\hline Good & 16.3 & (15.3) & -1.8 & (2.5) & 0.7 & $(0.1)$ \\
\hline Industrial & & & & & & \\
\hline Buy & 27.8 & $(23.6)$ & 4.9 & (1.3) & 1.0 & $(0.1)$ \\
\hline Hold & 22.3 & $(20.5)$ & 0.0 & $(0.0)$ & 1.0 & $(0.0)$ \\
\hline Sel1 & 15.6 & $(18.3)$ & -4.4 & (1.4) & 0.9 & $(0.0)$ \\
\hline
\end{tabular}

Note: The portfolios are formed each year. For the portfolios based on firm size, size is measures by market value of equity, the small portfolio consists of the bottom five percent of firms each year, the large portfolio the top five percent, and the medium portfolio consists of the remainder. For portfolios based on past performance, past performance is measured by the return of the stock in the five years up to the creation of the portfolio, the portfolios are defined analogously to the size portfolios. Industrial firms are defined as all firms with one digit SIC 1 to 4 . For the industrial firms, the portfolios are based on the change in shares outstanding. See table 5 for a definition of the industries. The portfolios consist of the bottom five percentiles of firms based on the change in shares outstanding (buy) the top five percentiles (sell) and the remainder (hold). The returns are for the five years following the creation of the portfolio and are annualized by dividing by five. Standard deviations of the returns and standard errors of the coefficients are in parentheses. The standard errors are corrected for possible serial correlation. 


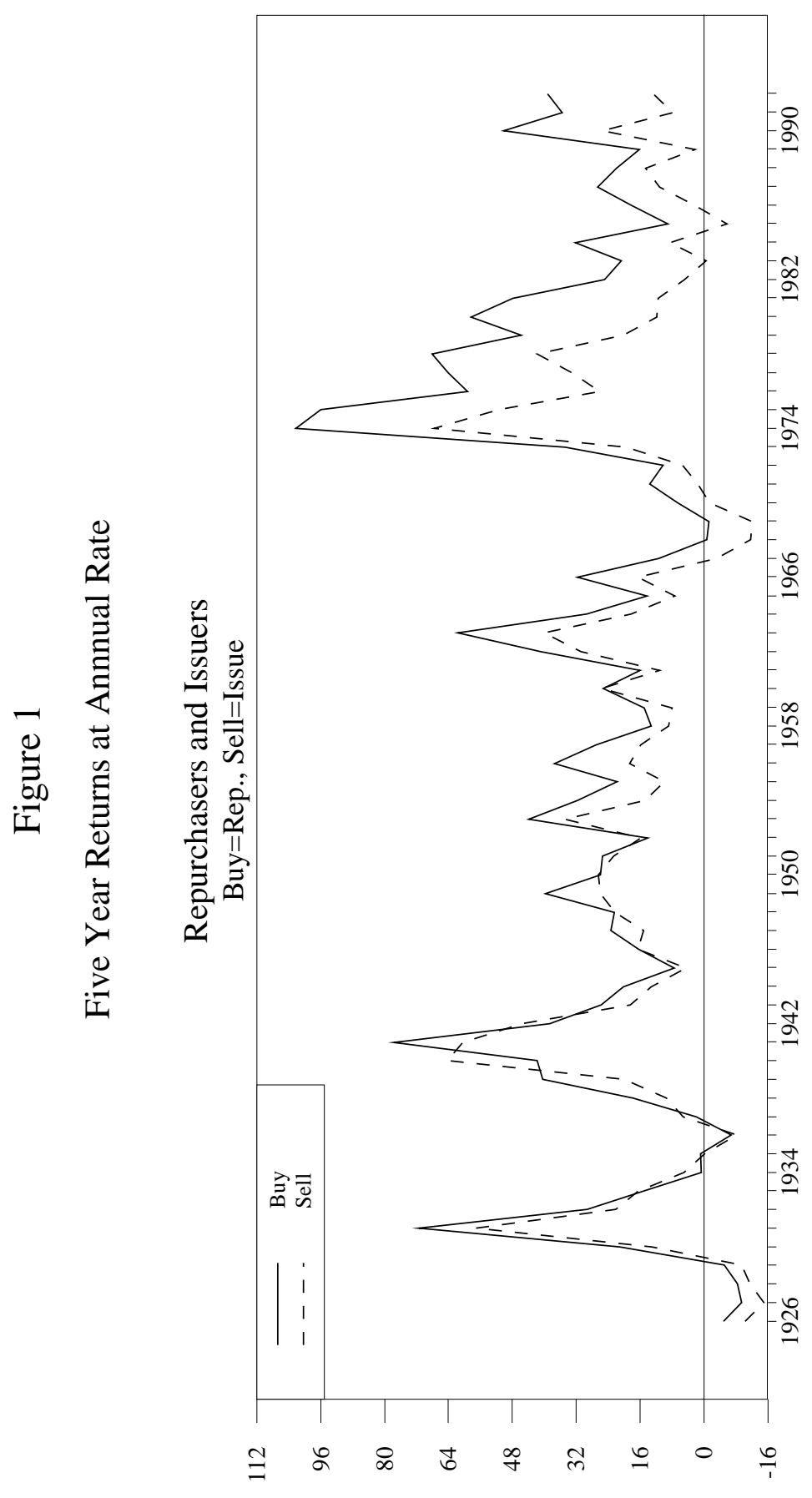

१นอว.ว

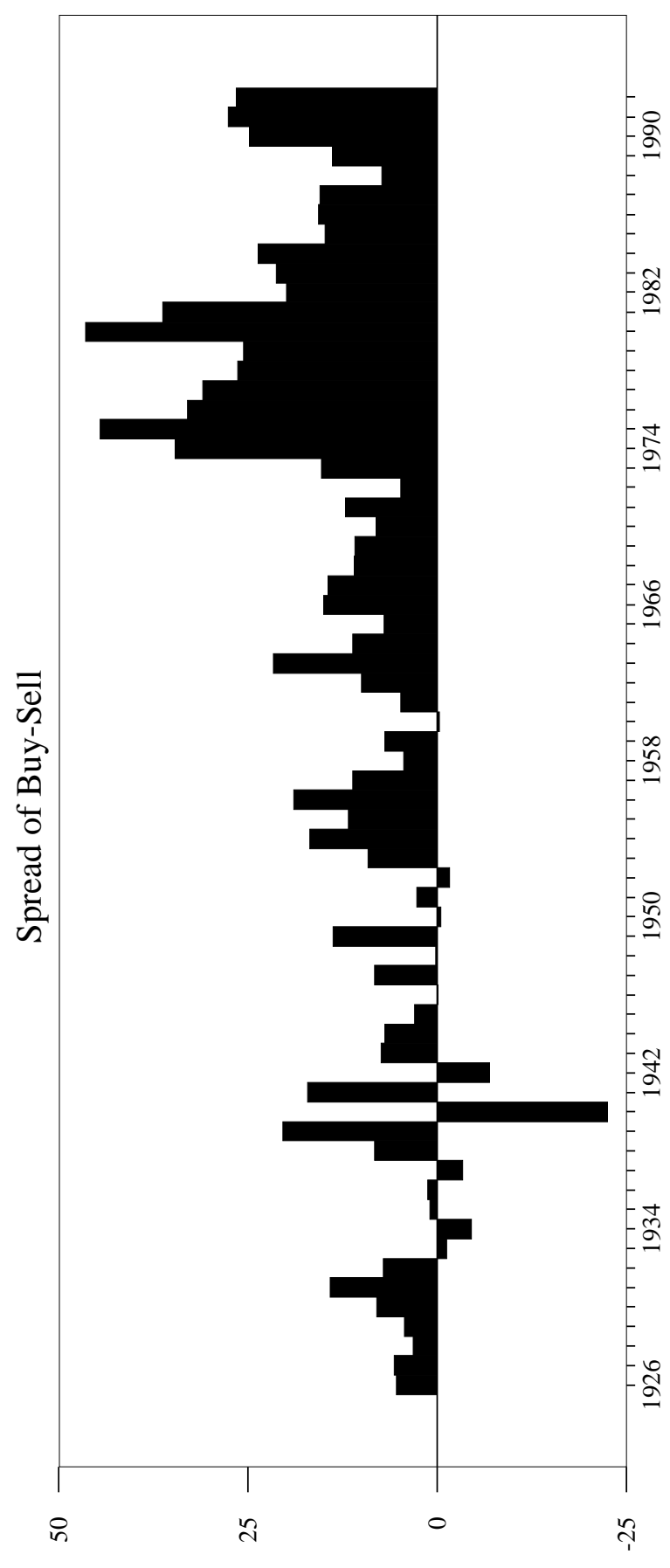

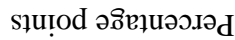




\section{References}

Asquith, Paul and David W. Mullins, 1986, Equity issues and offering dilution, Journal of Financial Economics 15, 61-89.

Banz, Rolf W., 1981, The relationship between return and market value of common stocks, Journal of Financial Economics 9, 3-18.

Cambpel1, John Y. and Robert J. Shiller, 1988, The dividend-price ratio and expectations of future dividends and discount factors, The Review of Financial Studies 1, 195-228.

Chopra, Navin, Josef Lakonishok and Jay R. Ritter, 1991, Measuring abnormal performance: Do stocks overreact, Journal of Financial Economics 1992, 235-268.

Dann, Larry, 1981, Common stock repurchases: An analysis of returns to bondholders and stockholders, Journal of Financial Economics 9, 115-138.

De Bondt, Werner F. M. and Richard Thaler, 1985, Does the stock market overreact?, The Journal of Finance 40, 793-808.

Fama, Eugene F. and Kenneth R. French, 1988, Permanent and temporary components of stock market prices, Journal of Political Economy 96, 246-273.

Fama, Eugene F. and Kenneth R. French, 1992, The cross-section of expected stock returns, The Journal of Finance 47, 427-465.

Hansen, Lars P., 1982, Large sample properties of generalized method of moments estimators, Econometrica 50, 1029-1054.

Ibbotson Associates, 1994, Stocks, Bonds, Bills and Inflation 1991 Yearbook, (Ibbotson Associates, Inc., Chicago, I11.).

Ikenberry, David, Josef Lakonishok and Theo Vermaelen, 1995, Market underreaction to open market share repurchases, Journal of Financial Economics 39, 181-208.

Jensen, Michael C., 1969, Risk, the pricing of capital assets and the evaluation of investment portfolios, Journal of Business 42, 167-247.

Lakonishok, Josef and Theo Vermaelen, 1990, Anomalous price behavior around repurchase tender offers, Journal of Finance 45, 455-477. 


\section{References (cont.)}

Loughran, Tim, and Jay R. Ritter, 1995, The new issues puzzle, The Journal of Finance 50, 23-51.

Masulis, Ron, 1980, Stock repurchase by tender offer: An analysis of common stock price changes, Journal of Finance 35, 305-318.

Masulis, Ron and A. N. Korwar, 1986, Seasoned equity offerings: an empirical investigation, Journal of Financial Economics 15, 91-118.

Mikkelson, W. H. and M. M. Partch, 1986, The valuation effects of security offerings and the issuance process, Journal of Financial Economics 15, 31-60.

Newey, Whitney K., and Kenneth D. West, 1987, A simple positive-definite heteroskedasticity and autocorrelation consistent covariance matrix, Econometrica 55, 703708.

Nelson, William R., 1999, Why does the change in shares predict stock returns?, Finance and Economics Discussion Series, Federal Reserve Board, Washington D.C., (forthcoming).

Poterba, James M. and Lawrence H. Summers, 1988, Mean reversion in stock prices: evidence and implications, Journal of Financial Economics 22, 27-59.

Rosenfeld, A., 1982, Repurchase offers: Information adjusted premiums and shareholder's response, Working Paper, Purdue University.

Vermaelen, Theo, 1981, Common stock repurchases and market signalling, Journal of Financial Economics 9, 139-183.

, 1984, Repurchase tender offers, signalling and managerial incentives, Journal of Financial and Quantitative Analysis 19, 163-183.

White, Halbert, 1980, A heteroskedasticity-consistent covariance matrix estimator and direct test for heteroskedasticity, Econometrica 48, 817-838. 